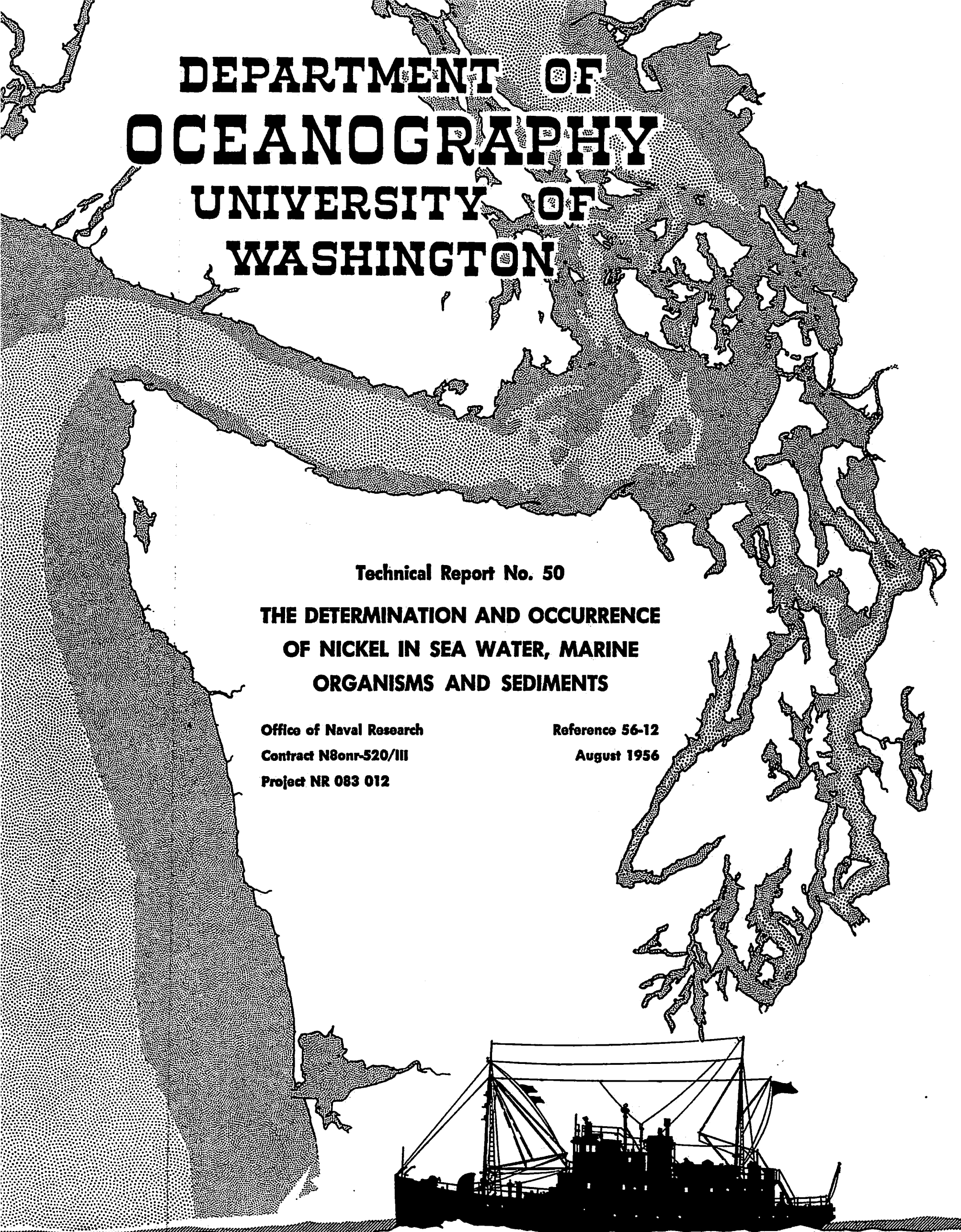




\section{UNIVERSTTY OT WASHINGTON DEPARTMENT OF OCEANOGRAPHY Seattle, Washington}

Technical Report No. 50

THE DETERMINATION AND OCCURREIVE OF NICKTL

IN STA WATER, NIARINE ORGANISMS, AND SIDIIIONTS

by

Taivo Laevastu and Thomas G. Thompson

\section{Office of Naval Research}

Contract N8onr-520/III

Project NR 083012

Reference 56-12.

August 1956

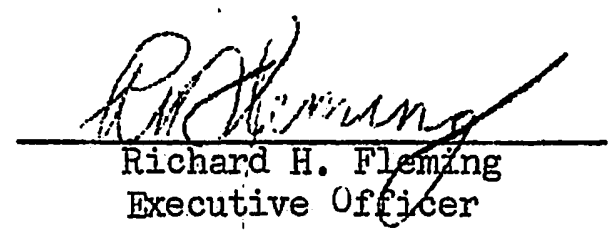

REPRODUCTION IN WHOLE OR IN PART.

IS PERMITTED FOR ANY PURPOGE OF:

THE UNITED STATES GOVERNMENT. 


\section{THE DETERMINATION AND OCCURRENCE OF NICKEI IN \\ SEA WATER, MARINE ORGANISMS, AND SEDIMENTS \\ by \\ Taivo Laevastu and Thomas G. Thompson}

ABSTRACT

The occurrence of nickel in sea water and certain materials of geologic and biologic origin has been reviewed. Methods for the analysis of nickel in sea water, in particulate material, and in marine organisms were investigated and modified. Nickel was satisfactorily recovered from sea water using sodium carbonate solution as the precipitant. The water should be treated immediately after sampling to minimize loss of nickel from solution through biological activity. In the preliminary treatment of marine organisms for nickel analysis, wet combustion was preferred to direct ashing as considerable nickel appears to be carried off with the smoke.

Sea water from Puget Sound and adjacent areas contain about 0.034 ug.-at. of nickel per kilogram in solution and 0.005 ug.-at. of nickel as particulate. River and lake waters contain slightly less soluble nickel than found in sea water. Plankton were found to contain twice as much nickel as the higher marine plants and ten times that found in the fish and mollusks. Indications are that plankt on from the euphotic layers contained about twice the concentration found near the aphotic zone, and that nickel is probably concentrated by bacteria. Plants and animals concentrate nickel in their calcareous skeletons in the same degree as in soft tissues.

The amount of nickel in sediments collected across the cont1nental shelf to the deep sea increased as the depth of water and distance from shore increased. Nickel is apparently halmyrolysed from shallowwater sediments and enriched in deep-sea deposits by several scavengers. 


\title{
The Determination and Occurrence of Nickel in Sea Water, Marine Organisms, and Sediments ${ }^{1}$ ).
}

\author{
By
}

\author{
Taivo Laevastu and Thomas G. Thompson, \\ Department of Oceanography, University of Washington, Seattle.
}

\section{Introduction.}

The objectives of this investigation were to (1) review the literature dealing with the occurrence of nickel in sea water and in marine organisms, and examine the methods previously used for the estimation of nickel in marine organisms, (2) devise a convenient and reliable method for the determination of minute quantities of nickel in natural waters, (3) determine the concentrations of nickel occurring in the waters of the Puget Sound region, and (4) investigate the occurrence of nickel in certain marine fish, plankton, and deposits of the Puget Sound region.

\section{Previous Studies on the Occurrence of Nickel in Sea Water, Organisms, Sediments, and Rocks.}

Relatively few analyses of nickel in sea water are given in the literature. The data available have been summarized in Table 1 . The concentrations given range from $0.002 \mu \mathrm{g}$.-at. of nickel for the North Sea to 0.131 $\mu$ g.-at. for Sevastopol Bay in the Black Sea. In most of the papers cited nothing is said about precautions taken to prevent contamination of the samples or corrections made for traces of nickel in the reagents utilized. The data available vary by more than one order of magnitude, and due to the meagreness of information it is impossible to state whether the differences are due to regional or seasonal variations, or to the sensitivities or errors in the methods employed for analysis.

1) Contribution No.192 from Department of Oceanography, University of Washington, Seattle, Washington, U.S. A. 
Table 1.

Amounts of nickel in water as reported by various investigators.

Place of collection

North Sea

Sea water (est.)

Skagerak, Gullmarfjord

Black Sea

Sea water (est.)

Black Sea, $1700 \mathrm{~m}$.

Black Sea, Sevastopol Bay

Black Sea, Karedag Biol. Stat.

Barents Sea, off Yarnysh Bay

Sea water, avg. (est.)

20 miles off Plymouth, $20 \mathrm{~m}$. depth,

22. II. 50

Ardencaple Bay, $0.5 \mathrm{~m}$. depth, 25. VI. 50

Atlantic Bridge, $15 \mathrm{~m}$. depth, 27. VI. 50

Pacific Ocean, off Shirahama, Wakayama, 20. X. 50

Average:

River waters, average

Lake waters, average "/g. $/ \mathrm{Kg}$. " g. -at. $/ \mathrm{Kg}$. Investigators and References

$0.12 .002 \quad$ Ernst and Hörmann (1936)

$1.0 \quad .017 \quad$ Maljuga (1939)

$.5 \quad .0085$ I. and W. Noddack (1939)

6.0 102 Maljuga (1942), according to Vinogradov (1944)

$3.0 \quad .051 \quad$ Vinogradov (1944)

4.5 $.076 \quad$ Maljuga (1945)

$7 \cdot 7 \quad \cdot 131 \quad$ Maljuga (1945)

$5.1 \quad .087 \quad$ Maljuga (1945)

$3.4 \quad .058 \quad$ Maljuga (1945)

$3.4 \quad .058 \quad$ Maljuga (1945)

5.5 093 Black and Mitchell (1952)

$1.5 \quad .025 \quad$ Black and Mitchell (1952)

1.5 $025 \quad$ Black and Mitchell (1952)

$0.75 \quad .013 \quad$ Ishibashi (1953)

$3.4 \quad .053$

4.8 $.082 \quad$ Maljuga (1945)

$17 \quad .29 \quad$ Maljuga (1945)

The amount of nickel reported in materials of geologic or biologic origin by other investigators is given in Tables 2 and 3 . These data show marked variation in the trace quantities of nickel in different rock formations. Besides meteorites and ore formations the basic igneous rocks, red clays and organic sediments are the richest in nickel, whereas acid igneous rocks, sedimentary rocks, soils and shallow water sediments have the lowest nickel content. Some oolitic iron ores are relatively high in nickel.

There are marked differences in the quantities of nickel in plants and animals. I. and W. N o d d a ck (1939) state that the element must be essential for animal life because one kilogramme of dried organisms contained 41,000 times the amount of nickel contained in one kilogramme of sea water. They stated also that the concentration of cobalt in marine animals is about one-tenth that of the nickel concentration. $\mathrm{Bl} \mathrm{ack}$ and M i t ch ell (1952), employing similar reasoning, found a concentration factor of 540 for nickel in sea plants as compared to sea water. The concentration of cobalt was equivalent to about onefourth that of the nickel concentration of the plants. They also noted that the nickel concentrations were higher in spore-forming Laminaria than in those not forming spores, and that greater quantities of nickel occur in the plants in the summer than in the winter months. On the other hand, B e r trand and M âcheboe uf (1925) claimed that animals have far less nickel than cobalt in their tissues. $\mathrm{Kent}$ and 


\section{Table 2.}

Amounts of nickel in rocks, soils, and sediments as reported by various investigators.

\begin{tabular}{|c|c|c|c|}
\hline \multirow{2}{*}{$\begin{array}{c}\text { Element } \\
\text { Basic igneous rocks }\end{array}$} & $\mathrm{Ni}$ in $\mathrm{mg} . / \mathrm{Kg} . \quad \mathrm{N}$ & $\mathrm{Vi}$ in mg.-at. $/ \mathrm{Kg}$. & Investigators and References \\
\hline & $\begin{array}{l}65 \\
100-2,000\end{array}$ & $\begin{array}{l}1 \cdot 1 \\
1 \cdot 7-34 \cdot 0\end{array}$ & $\begin{array}{l}\text { Lundegårdh (1949) } \\
\text { Vogt (1923) }\end{array}$ \\
\hline Acid igneous rocks & $\begin{array}{l}\text { tr. }-5 \\
8\end{array}$ & .14 & $\begin{array}{l}\text { Vogt (1923) } \\
\text { Lundegårdh (1949) }\end{array}$ \\
\hline \multirow[t]{4}{*}{ Igneous rocks } & 80 & $1 \cdot 4$ & Sandell, Goldich (1943) \\
\hline & 200 & $3 \cdot 4$ & Clarke (1924) \\
\hline & 48 & .82 & Lundegằrdh (1949) \\
\hline & 100 & 1.7 & nidt (1937) \\
\hline Oolitic iron ores & $-39,000$ & -664 & $\mathrm{Ma}$ \\
\hline Sedir & $\operatorname{tr} .-28$ & $\operatorname{tr} .-0048$ & 939) \\
\hline San & $2-8$ & $.034-14$ & ama, Sahama (1949) \\
\hline Sha & 24 & .41 & ama, Sahama (1949) \\
\hline $\operatorname{Lim}$ & 0 & 0 & Rankama, Sahama (1949) \\
\hline soils & 20 & .34 & Gol \\
\hline Soi & $8 \cdot 3-730$ & $\cdot 14-12 \cdot 5$ & $\mathrm{Ma}$ \\
\hline Met & 16,000 & 272 & Rankama, Sahama (1949) \\
\hline Asp & 3,000 & 51 & Well \\
\hline $\mathrm{Nap}$ & $50-1$ & $4 \cdot 25-.0$ & $\begin{array}{l}\text { DeGolyer (1924) quoted by } \\
\text { Maljuga (1939) }\end{array}$ \\
\hline Coal & $220-5 \cdot 2$ & $3.7-.089$ & Krat \\
\hline Coa & 700 & 12 & $G$ \\
\hline uus ash & 00 & 1.7 & 1954) \\
\hline Red clay (composite) & 253 & $4 \cdot 31$ & Clarke (1924) \\
\hline Red clay (composite) & 259 & $4 \cdot 41$ & You \\
\hline Red clay, Pacific Ocean & 164 & 2.79 & rgren (communication) \\
\hline Terrigenous clays & 498 & $8 \cdot 49$ & Clarke (1924) \\
\hline & & $4 \cdot 25$ & \\
\hline sediments & 11 & 1.87 & Maljuga (1945) \\
\hline diments & & & 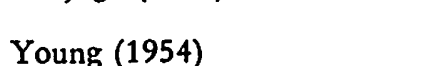 \\
\hline Manganes & 7,700 & 131 & $\begin{array}{l}\text { Irvine and Gibson, } \mathrm{c} \\
\text { Maljuga (1945) }\end{array}$ \\
\hline
\end{tabular}

McCance (quoted by Monier-Williams, 1949) found that in humans much of the nickel consumed is discharged in the urine. Stiles (1946) states that nickel is more frequent in animals than cobalt, that nickel is irregularly distributed, and that little is known of its presence in various organs. He indicates that the availability of nickel to plants increases the growth but that there is no evidence that the element is essential. W a l l a c e (1952) has demonstrated that excess nickel is toxic to plants and organisms and that its presence in excess may induce an iron deficiency. Vin og radov (1953) states that $\mathrm{Pau}$ a is (1936) has found a concentration of nickel in the gills and liver of molluscs.

Gold smid t (1954) assumed that divalent nickel accompanies divalent magnesium, cobalt, and iron because of the similarity of the ionic radii. 


\section{Table 3.}

Amounts of nickel in plants and animals as reported by various investigators.

Element

Seaweeds

Marine plants

Freshwater algae

Fruits and grains

Lettuce, cabbage, spinach, and peas

Pastures

Whole plants on living basis

Calanus finmarchicus

Fish

Osmerus eperlanus

Gadus sp.

Polychaetes

and molluscs

Mytilus edulis (meat)

Sponges

Marine animals

Land animals

Human liver

Living matter
$\mathrm{Ni} \mathrm{mg./Kg.} \quad \mathrm{Ni} \mathrm{mg.-at.} / \mathrm{Kg}$.

Dry matter Dry matter

$\begin{array}{ll}3.7 & .063 \\ .099-.83 & .0017-.014 \\ .5 & .0085 \\ .0017-.012 & .00003-.0002 \\ .01-2.0 & .00017-.034 \\ .9 & .015 \\ 1.5-3.0 & .026-.051 \\ .56-3.65 & .01-.062 \\ & \\ .013-1.5 & .00022-.026 \\ 1.2 & .0204 \\ .015 & .00026 \\ .68 & .0116 \\ 1.1 & .0187 \\ & \\ 8-100 & .14-1.7 \\ 2.35 & .040 \\ 1.8-6.14 & .036-10.45 \\ 20.6 & .35 \\ .5 & .0085 \\ .01-20 & .00017-.34 \\ .01-.05 & .00017-.00085 \\ .09 & .0015 \\ .01-20 & .00017-.34\end{array}$

Investigators and References .

Black and Mitchell (1952)

Maljuga (1939)

Maljuga (1939)

Maljuga (1939)

Maljuga (1939)

Bertrand and Mokragnatz (1930)

Bertrand and Mokragnatz (1930)

Scott and Mitchell (1943)

Maljuga (1939)

Maljuga (1939)

Bertrand and Mâcheboeuf (1925)

Bertrand and Mâcheboeuf (1925)

Maljuga (1945)

Fox and Ramage (1931)

Bertrand and Mâcheboeuf (1925)

Bowen and Sutton (1951)

I. and W. Noddack (1939)

Maljuga (1939)

Maljuga (1939)

Maljuga (1939)

Bertrand and Mâcheboeuf (1925)

Vinogradov (1937)

\section{The Determination of Nickel in Sea Water.}

Ernst and Hörmann (1936) isolated nickel from the major constituents of sea water by adding a solution of a ferrous salt and then precipitating the ferrous and nickel sulphides with ammonium sulphide. I shibashi et al. (1951) employed a ferric salt solution to serve as a collector, precipitating the traces of nickel with the ferric hydroxide by addition of ammonium hydroxide. Samples of 40 to 60 litres were taken for each analysis. Several other investigators used spectroscopic methods, concentrating samples of water by evaporation.

In the present investigation, the addition of a collector was unnecessary, because in an alkaline solution the traces of nickel were carried down with the precipitates of magnesium hydroxide or carbonate. The first reagent employed was sodium hydroxide, but this proved unsatisfactory because the analytical grade chemical contained as much as one microgramme of nickel per gramme. Sodium carbonate was obtainable practically free of nickel, and this was the reagent used. For the final estimation of nickel the procedure given by $\mathrm{S}$ a $\mathrm{ndell}$ (1950) was employed. The complete procedure is as follows:- 


\section{Collection of samples.}

Extreme care was exercised in the collection of samples to prevent contamination. The water-sampling bottle described by $\mathrm{T}$ h o $\mathrm{m}$ p s o n and $\mathrm{Ch}$ ow (1955) insured the collection of samples at various depths free of contamination. Samples were treated for analysis immediately after collection. If this were not done, micro-organisms in the water would continue to grow and take up nickel from solution.

\section{Chemicals.}

All chemicals should be completely free of traces of nickel or blank determinations made to ascertain the quantities of nickel present.

Sodium carbonate solution: $50 \mathrm{~g}$. of reagent grade anhydrous sodium carbonate dissolved in 1 litre of distilled water.

Hydrochloric acid: $\quad$ Solutions of $6 \mathrm{~N}$ and $0.6 \mathrm{~N}$ prepared by dilution.

Ammonium hydroxide: Concentrated reagent grade.

Dimethylglyoxime:

A $1 \%$ solution is prepared by dissolving in ethyl alcohol.

Bromine water: Saturated solution.

Sodium citrate solution:

A $10 \%$ solution prepared by dissolving the salt in water.

Chloroform:

Reagent grade.

\section{Preparation of standard nickel solutions.}

Weigh out exactly $0.3365 \mathrm{~g}$. of nickel ammonium sulphate hexahydrate crystals or $0.0500 \mathrm{~g}$. of pure nickel wire. Dissolve the salt in redistilled water or the wire in dilute nitric acid, transfer quantitatively to a volumetric flask, and dilute to one litre. Ten $\mathrm{ml}$. of this solution is taken and diluted to exactly one litre. One $\mathrm{ml}$. of the latter solution is equivalent to 0.5 microgrammes of nickel $(0.0085 \mu \mathrm{g} .-\mathrm{at} . / \mathrm{ml}$.).

Pure nickel wire is the most desirable substance to employ for preparation of standard solutions. Other standard solutions were prepared with the hexahydrates of nickel chloride, nickel sulphate, and nickel ammonium sulphate. The results obtained from the different standards are illustrated in Figure 1 and show that of the hydrates, if it is necessary to use one as a standard, nickel ammonium sulphate is preferable.

\section{Procedure.}

Two-litre samples of sea water are filtered through a type HA millipore filter. The filtrate is assumed to contain all the nickel in true solution ( $\mathrm{L} \mathrm{e} \mathrm{w} \mathrm{is} \mathrm{and} \mathrm{Gold} \mathrm{be} \mathrm{r} \mathrm{g,} \mathrm{1954),} \mathrm{whereas} \mathrm{the} \mathrm{detritus}$ retained on the filter may be taken and analysed for nickel, as described later, and reported as particulate nickel.

One hundred $\mathrm{ml}$. of sodium carbonate solution is added to the 


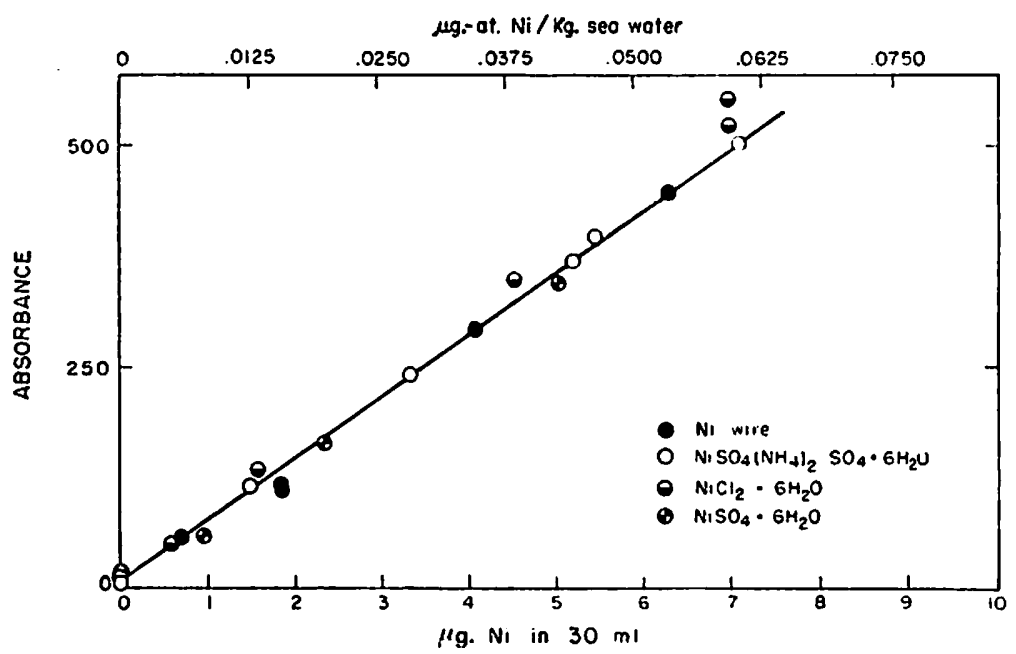

Figure 1. Nickel calibration graph.

filtrate which is then allowed to stand for about 12 hours. The supernatant liquor is syphoned through a millipore filter, and then the bulk of the precipitate is transferred to the filter. The residual precipitate is dissolved in a small quantity of $6 \mathrm{~N}$ hydrochloric acid, the solution transferred to a small beaker to which the bulk of the precipitate retained by the filter has been introduced. The filter is then washed quantitatively with $6 \mathrm{~N}$ hydrochloric acid and the washings combined with the solution resulting from dissolving of the precipitate. The total volume should not exceed $25 \mathrm{ml}$. and should be kept constant. This solution, after the addition of $15 \mathrm{ml}$. sodium citrate solution is made ammoniacal to a $\mathrm{pH} 8$. It is then cooled rapidly, transferred to a separatory funnel, $2 \mathrm{ml}$. dimethylglyoxime added, and then shaken with $3 \mathrm{ml}$. chloroform for about half a minute. The chloroform extracts the nickel dimethylglyoxime. It is drawn off into another separatory funnel, care being taken not to permit any of a possible slight precipitate that may have formed over the chloroform to pass into the funnel. This process of extraction is repeated twice. The combined extractions are then shaken with $5 \mathrm{ml}$. 1:50 ammonium hydroxide and the chloroform drained into another separatory funnel. The ammonium hydroxide is shaken with $2 \mathrm{ml}$. chloroform and the latter drained and combined with the previous chloroform solution. This solution is then shaken with $5 \mathrm{ml}$. $0.6 \mathrm{~N}$ hydrochloric acid, the nickel dissolving in the acid and the dimethylglyoxime being retained by the chloroform. The process is repeated. The combined solutions are then transferred to a flask which will permit eventual dilution to a volume of exactly $30 \mathrm{ml}$. Ten drops of bromine water are added, and after a few minutes ammonium hydroxide is slowly introduced until the bromine colour disappears. When this occurs, $0.5 \mathrm{ml}$. ammonium hydroxide is added in excess, followed by the addition of one $\mathrm{ml}$. dimethylglyoxime and the 


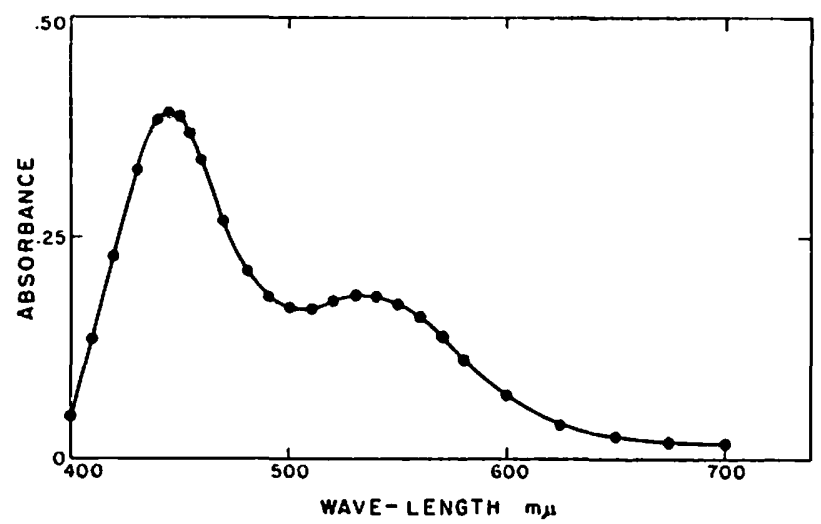

Figure 2. Absorbance of nickelic dimethylglyoxime complex.

solution made up to a volume of exactly $30 \mathrm{ml}$. It is then transferred to a $100 \mathrm{~mm}$. cell and its absorbancy determined with a Beckman spectrophotometer. The absorbancy of the solution is measured at $450 \mathrm{~m} \mu$. The full colour intensity develops almost immediately upon the addition of dimethylglyoxime. The measurement of the absorbancy is made 15 minutes after the addition of this reagent and transference to the cell.

\section{Preparation of calibration graph.}

Varying quantities of the standard nickel solution are pipetted into separatory funnels so that a range of from 0.5 to 10 microgrammes $(0.0085$ -0.170 microgramme atoms) of nickel are in six solutions. A volume of hydrochloric acid, equivalent to that used in dissolving the precipitated carbonates as described above, is added to each solution. Fifteen ml. of sodium citrate is introduced and each of the standard samples is treated in the same manner as given in the procedure, using the identical reagents in the same quantities. The absorbancies obtained are plotted against the concentration of nickel. From this graph (Figure 1) and from the absorbancies obtained on the water samples being analysed, the actual concentration of nickel may be ascertained. Figure 2 shows the absorbancy plotted against the wave-length.

By treatment of the standards in the manner described, there was compensation for errors occurring during the extraction processes and also for traces of impurities that might have been present in the reagents used.

\section{Comparison and validity of procedures.}

The method of Is hibashi ct al. (1951) was questioned, as complete retention of nickel by the ferric hydroxide precipitate might not occur because of the exceedingly small concentration of nickel in sea water and the tendency to form soluble nickel ammonia ions. A comparison of the Is h ib a sh i procedure with the method proposed was made, using, however, only two litres of water instead of 60 litres 
required by Is hibashi. A sample of sea water was analysed with ferric hydroxide used as the collector in an ammoniacal solution. Nickel was also determined on a similar two-litre sample by precipitating the collectors already present in the water with sodium carbonate. In each case check determinations were made and the following results were obtained:-

\begin{tabular}{|c|c|c|c|}
\hline & Microgramme- & s nickel $\mathrm{p}$ & of sea water \\
\hline & Portion A & Portion $\mathrm{E}$ & Average \\
\hline $\begin{array}{l}\text { Method of Is hib a shi et al. } \\
\text { Sodium carbonate method }\end{array}$ & $\begin{array}{l}.015 \\
.0255\end{array}$ & $\begin{array}{l}.017 \\
.024\end{array}$ & $\begin{array}{l}.016 \\
.025\end{array}$ \\
\hline
\end{tabular}

These results demonstrate that greater quantities of nickel were precipitated when the natural collectors and sodium carbonate were used than when ferric hydroxide in ammoniacal solution was employed.

When a solution containing nickel is made ammoniacal, the very soluble nickel ammonia ion tends to form. However, in the presence of ferrous or ferric hydroxides most of the nickel will be retained by the precipitates, but due to the exceedingly small concentration of nickel occurring in sea water the precipitation is not quantitative.

To test further the validity of the sodium carbonate procedure, it was first deemed desirable to prepare a synthetic sea water, free of nickel, and to which known concentrations of nickel could be added. However, the synthetic sea water prepared contained nickel (present as an impurity in the chemicals used) in quantities far greater than the natural sea water and the concentrations of nickel proposed for addition, cven though reagent grade chemicals were employed. Therefore, several different samples of natural sea water were analysed for nickel, varying concentrations of known amounts of nickel were then added to other samples of the same waters, and the total nickel was determined. The results were as follows:-

\begin{tabular}{|c|c|c|c|}
\hline $\begin{array}{c}\mathrm{Ni} \text { in } 2 \text { litres sea water } \\
\mu \mathrm{g} \text {.-at. }\end{array}$ & $\begin{array}{l}\mathrm{Ni} \text { added } \\
\mu \mathrm{g} \text {.-at. }\end{array}$ & 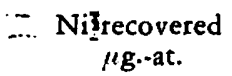 & $\begin{array}{l}\text { Percentage } \\
\text { recovered }\end{array}$ \\
\hline \multirow[t]{2}{*}{$\begin{array}{l}.055 \\
.055 \\
.055 \\
.055 \\
.0485 \\
.053\end{array}$} & $\begin{array}{l}.085 \\
.1365 \\
.085 \\
.085 \\
.085 \\
.0425\end{array}$ & $\begin{array}{l}.123 \\
.169 \\
.143 \\
.136 \\
.146 \\
.095\end{array}$ & $\begin{array}{r}80 \\
83 \\
103 \\
95 \\
115 \\
99\end{array}$ \\
\hline & & Mean re & ry: 96 \\
\hline
\end{tabular}

Influence of storage on the nickel content of water.

It is well known that storage of samples of sea water before analysis markedly affects the concentration of some of the nutrient salts. It was found that the concentration of nickel was affected similarly.

Large samples of water were collected and divided in five portions. One portion was filtered and analysed immediately for nickel. Other portions were stored in darkness or subjected to the action of artificial illumination for a period of two to three weeks before filtration and 
analysis. To another portion hydrochloric acid was added before storage and to still another carbon disulphide. The final analyses of these various portions yielded the following results:-

Immediate filtration and analysis

Storage in darkness for 3 weeks

Storage in darkness for 2 weeks

Storage in light for 3 weeks

Storage in light for 2 weeks

Addition of $7.5 \mathrm{ml} .12 \mathrm{~N} \mathrm{HCl}$ per litre

before storage. Stored for 3 weeks

Stored for 2 weeks

Addition of several drops of CS2

before storage. Stored for 3 weeks

$\begin{array}{cc}\text { Sample I } & \text { Sample II } \\ \text { Hg.-at. } & \mathrm{Ni} / \mathrm{Kg} . \\ 0.036 & 0.031 \\ .010 & .028 \\ .026 & .024 \\ & \\ .041 & .045 \\ & \\ .016 & .022\end{array}$

These results demonstrate that nickel is removed from solution by biological action on storage. The addition of hydrochloric acid halted biological action but caused some of the particulate nickel to go into solution, whereas carbon disulphide may have caused precipitation of some of the nickel. Thus filtration and analysis immediately after collection of samples is essential if one wishes to differentiate between the nickel actually in solution and particulate nickel. If one is interested solcly in the total nickel content of a sample, then immediately after collection, two litres of the sample should be measured, transferred to an appropriate container, and $100 \mathrm{ml}$. of sodium carbonate solution added. Continuation of the analysis may then proceed according to convenience.

\section{Determination of Nickel in Marine Organisms.}

Two methods for the preliminary treatment of various samples of biological origin prior to the determination of nickel were studied, namely, direct ashing and wet combustion. The results, with the two methods used for destruction of organic matter, as evidenced by the amount of nickel actually determined, are given in Table 4 . In all materials, with the exception of plankton, abnormally low results were secured on samples that had been ashed. Due to the high mineral content of plankton (as indicated by the voluminous and porous residue obtained on ignition) there were only slight differences observed in the results obtained by the two methods.

When wet combustion was deemed advantageous, the following procedure was used:- 2 to $8 \mathrm{~g}$. of oven-dried material were weighed in an Erlenmeyer flask, treated with nickel-free concentrated sulphuric acid, and heat applied until the mass was colourless or yellow-brown. When all organic matter had been destroyed and much of the excess sulphuric acid fumed off, the residue was cooled and then treated with $10 \mathrm{ml}$. $6 \mathrm{~N}$ hydrochloric acid. The solution was diluted to about $25 \mathrm{ml}$., heated again, and any residue was removed by filtration, the filtrate 
Table 4.

Comparison between ashing and wet combustion of biological materials.

\begin{tabular}{lcc} 
& \multicolumn{2}{c}{ Ni in mg.-at./Kg. dry matter } \\
Wet combustion & Ashing \\
Plankton & .104 & .101 \\
Mackerel meat & .005 & .0035 \\
Perch meat & .007 & .0035 \\
Kelp & .012 & .007 \\
Dorsal skin from flounder & .017 & .0085
\end{tabular}

being received in a separatory funnel. Fifteen $\mathrm{ml}$. of sodium citrate solution was then added, and the analysis for nickel was continued as described above. The sulphuric acid used for wet combustion should be analysed for nickel by performing several blank determinations, and the correction applied.

\section{Analytical Results.}

Nickel in solution in sea water.

In Table 5 are given the results obtained on samples of filtered and unfiltered sea water collected in Puget Sound and adjacent areas. The mean value found for filtered sea water was .034 microgramme atoms of nickel per kilogramme of sea water; extreme values varied from 0.024 microgramme atoms for a water collected at the surface in Hood Canal in May 1954 to 0.046 microgramme atoms for a sample secured from 35 metres in Puget Sound off Golden Gardens in October 1954. These data are more than one order of magnitude higher than the values given by $\mathrm{Erns} t$ and $H \ddot{o r m}$ an $n$ (1936) and twice as great as those cited by $I s \mathrm{~h} \mathrm{i} \mathrm{b} \mathrm{a} \mathrm{s} \mathrm{hi} \mathrm{(1953)} \mathrm{but} \mathrm{are} \mathrm{in} \mathrm{agreement} \mathrm{with} \mathrm{the} \mathrm{concentra-}$ tions given by B l a ck and $\mathrm{M}$ i t che 11 (1952).

From the data given in Table 5, it appears that the concentration of nickel in the surface waters is less than that obtained in waters of the depths. A seasonal variation in the concentration of nickel, and that nickel is not a limiting factor in organic production, are also indicated.

Interstitial water.

Water was collected from holes dug in several mud flats during low tide. The nickel content, as indicated from data presented in Table 5, was slightly higher than that of the adjacent waters.

River and lake water.

Samples of water taken from Lake Washington and two rivers, the Hoh and Sol Duc, were analysed for nickel, and the data given in Table 5 show that the nickel content of these fresh waters was slightly lower than that of sea water. 


\section{Table 5.}

Nickel content of waters in Puget Sound and adjacent areas.

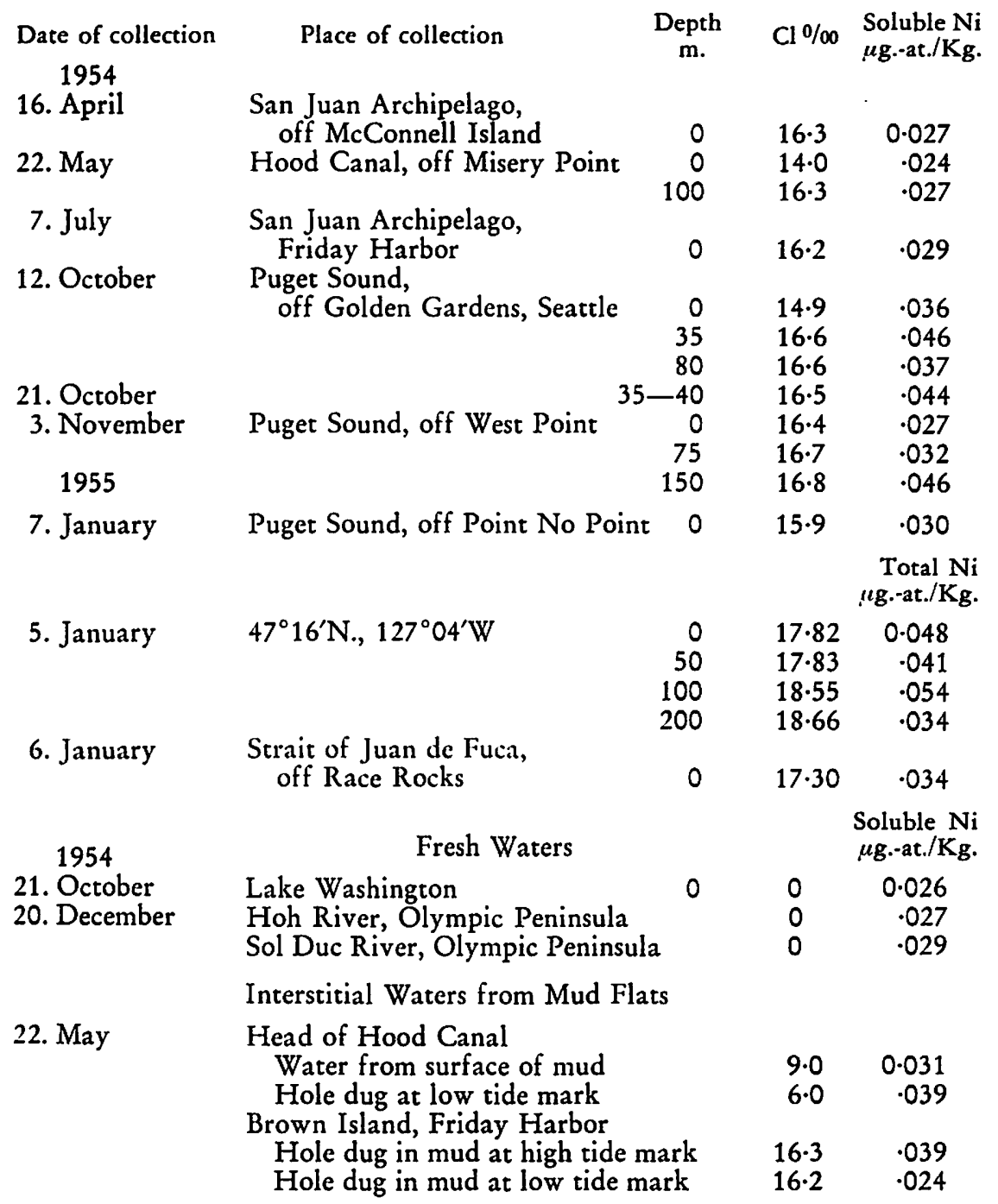

\section{Particulate nickel.}

The residues retained by the millipore filters were analysed for nickel and the quantities reported as particulate nickel per kilogramme of water. The results obtained on detritus are shown in Table 6. The amount of particulate nickel averaged about 0.005 microgramme atoms per kilogramme of water, or about $15 \%$ of the concentration of the soluble nickel. 
Table 6.

Particulate nickel in water from Puget Sound and adjoining areas.

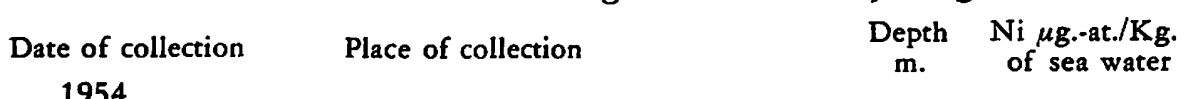

16. April

12. October

San Juan Archipelago, off McConnell Island $\quad 0 \quad 0.007$

Puget Sound, off Golden Gardens, Seattle $\quad 0 \quad .003$

21. October

3. November

Puget Sound, off West Point

21. October

Fresh water from Lake Washington

.005

Hoh River, Olympic Peninsula

.154

Sol Duc River, Olympic Peninsula

.021

The particulate nickel in the waters of the two rivers investigated was considerably higher than that found in sea water, as shown by the data in Table 5. The Hoh River water contained much finely divided clay in suspension and the particulate nickel was much higher than that of the Sol Duc. The nickel present was of mineral origin.

The relatively high concentration of nickel in the particulate matter, as compared with the soluble nickel, gives an explanation of the very high values reported by $\mathrm{M} \mathrm{a} \mathrm{l} \mathrm{jug} \mathrm{a}(1939,1945)$ for river and lake water, as this investigator did not distinguish between soluble and particulate nickel.

\section{Nickel in marine plankton.}

The concentration of nickel in marine plankton is given in Table 7. The plankton was collected with metal-free nets, the major components determined under a binocular microscope, and the abundance reported as percentage by volume. The plankton samples were ashed before analyses for nickel were made.

F le ming (1940) reported that in general one gramme of dry plankton is equivalent to $16 \mathrm{~g}$. of fresh plankton. In accumulating the data given in Table 7 , this statement was substantiated; but, as would be expected, there is a deviation from each particular sample depending upon its biological composition.

From the data presented, it appears that plankton collected in the spring months contains more nickel than that secured in the autumn. The nickel content of plankton collected at or near the surface showed a concentration of nickel twice that of samples obtained in deeper water. The concentration factor of nickel in fresh plankton in relation to the concentration of nickel in sea water was found to vary from $170: 1$ to $970: 1$ with an average value about $500: 1$. The corresponding concentration factor for phosphates is about $20,000: 1$. This shows that plankton organisms are highly selective as to intake of ions. 
Table 7.

Nickel content of marine plankton.

Date of collection 1954
Place of collection
Depth $\%$ dry

Constituents

by volume $\%$
$\mathrm{Ni} \mathbf{m g}$-at./Kg. dry matter

24. April

Puget Sound, off Golden Gardens, Seattle 0

Pseudocalanus

85

10

8.1 Pseudocalanus

23. May

$$
\begin{aligned}
& \text { Hood Canal, } \\
& \text { off Misery Poin } \\
& \text { San Juan } \\
& \text { Archipelago, } \\
& \text { East Sound }
\end{aligned}
$$
off Misery Point

Sagitta

Peridinium

Pseudocalanus

Pseudocalanus

2. July

Scbröderiella and Chaetoceras

4.8 Other diatoms

Schröderiella and other diatoms 70

15. October

$$
\begin{array}{r}
\text { Puget Sound, } \\
\text { off Golden }
\end{array}
$$
Gardens, Seattle $11 \quad$ Coscinodiscus

In the Annual Report of the Institute for Seaweed Research (1953) it is stated that cobalt is assimilated by seaweeds during the processes of photosynthesis and emitted during the hours of darkness. As nickel is analogous to cobalt a preliminary test was performed in order to ascertain whether a similar behaviour could be noted, and thus give a possible explanation of the higher nickel content of surface plankton. Samples of sea water were taken, enriched by the addition of nickel; and living plankton was added. One bottle was placed in darkness for 30 hours and the other exposed to artificial light for a similar length of time. On filtration and the analysis of the waters, the following

\begin{tabular}{|c|c|}
\hline $\begin{array}{c}\text { Sea-water } \\
\text { Ni } \mu \mathrm{g} \cdot \text {-at. } / \mathrm{Kg} .\end{array}$ & $\begin{array}{c}\text { Plankton and } \\
\text { bacteria } \\
\mathrm{Ni} \mu \mathrm{g} \cdot-a t . / \mathrm{g} . \\
\text { dried material }\end{array}$ \\
\hline $\begin{array}{r}0.073 \\
.025 \\
.027\end{array}$ & $\begin{array}{r}0.078 \\
.204 \\
.150\end{array}$ \\
\hline
\end{tabular}
results were obtained:-

Original nickel-enriched water

After 30 hours exposure to light with plankton

After 30 hours in darkness with plankton

These results demonstrate that besides the intake of nickel by photosynthetic activities, the decrease in concentration of nickel in the water may be attributed to selective adsorption or absorption or to assimilation by bacteria. It was noted that there was a decided growth of bacteria in the bottles after standing 30 hours. B ow e $n$ and $S u t t o n$ (1951) 
Table 8.

Fish

Phanerodon tureatus (fllesh)

Phanerodon tureatus (flesh)

Taeniotoca lateralis (flesh)

Nickel in fish.

Pneumatophorus diego (flesh)

Pneumatophorus diego (flesh)

Platichtys stellatus (flesh)

Platichtys stellatus (dorsal skin)

Oncorbynchus kisutch (flesh)

Oncorbynchus kisutch (sperm)

Oncorbynchus kisutch (blood)

Oncorbynchus kisutch (liver)

Sardinops caerulea

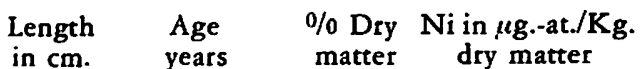

$\begin{array}{rrrr}32.5 & 7+ & 15.4 & 7.0 \\ 23.0 & 3+ & 21.7 & 6.0 \\ 20.0 & 2+ & 19.6 & 7.0 \\ 24.0 & & 28.6 & 5.5 \\ 33.0 & & 28.6 & 5.5 \\ 29.5 & 5+ & & 9.2 \\ & & & 17.0 \\ 58.0 & 2+ & & 28.9 \\ & & & 20.3 \\ & & & 13.5 \\ & & & 8.5 \\ & & & 5.1\end{array}$

Molluscs

Siliqua patula (flesh)

Most of the above specimens were collected and identified by Dr. Lauren $R$. D on ald son and Dr. Allan C. D e L a c y, of the School of Fisheries, University of Washington, and John S. Thompson, of the Washington State Department of Fisheries.

assumed that bacteria associated with marine sponges could concentrate nickel in much greater quantities than the sponges free of bacteria. E rics on and Lew is (1953) made a similar assumption for the assimilation of cobalt by bacteria attached to seaweeds.

Nickel in marine plants.

Some plants were collected in the late spring and early summer of 1954 and prepared for analysis by ashing of the material. No detailed data are here presented because of the unreliability of the analyses due to ashing. The mean concentration of nickel in the plants examined by this method was 85 microgramme atoms per kilogramme of dried material; but as shown in Table 4, this average figure is low because of ashing.

Nickel in fish.

Analyses for nickel on several species of fish were made, and the data are given in Table 8. The flesh of Oncorbynchus kisutch contained about three times the concentration of nickel as found in that of the other fish examined, and about twice that of the molluscs analysed. The nickel content found in the flesh of the fish examined, with the exception of Oncorbynchus kisutch, is the same order of magnitude as that reported by $\mathrm{M}$ a l jug a (1939) for marine animals.

Nickel in calcareous skeletons of plants and animals.

As $\mathrm{R}$ a $\mathrm{n} \mathrm{k} \mathrm{a} \mathrm{m}$ a and $\mathrm{S}$ a h a $\mathrm{m} \mathrm{a} \mathrm{(1949)} \mathrm{report} \mathrm{the} \mathrm{absence} \mathrm{of} \mathrm{nickel}$ in limestone, it was deemed desirable to ascertain the absence of the 
Table 9.

Nickel in calcareous skeletons of plants and animals.

Plants

Place of collection

$\mathrm{Ni} \mu \mathrm{g} .-\mathrm{at} . / \mathrm{Kg}$.

Coralliniaceae

(Lithothamnion and other genera) Off Sarasota, Florida 70

Animals

Macoma nubilus

Pecten diegensis

Mytilus californiensis

Puget Sound

Puget Sound

Puget Sound

$5 \cdot 3$

$7 \cdot 8$

$6 \cdot 0$

metal in biogen calcareous remains. A few analyses were made on recent clam shells and calcareous algae. The results are reported in Table 9 and show the same tenfold difference as given above for the nickel content of plants and animals. From this limited data, it might be concluded that plants and animals concentrate nickel in the calcareous skeletons in the same degrec as in their organic tissues.

Nickel in marine sedimentary deposits.

Samples of marine sediments from different areas were examined for their nickel content, and the results secured are shown in Table 10.

Two of the samples analysed were shallow-water sediments from the coast of Florida and were supplied by Dr. Howard G o u ld. The composition as well as the nickel content of these samples are comparable to sandstone. The sample from Charlotte Harbor contained more nickel than that from Tampa Bay and was also richer in organic matter, which may possibly explain the higher nickel content.

The sediment samples from Puget Sound and the adjacent Strait of Juan de Fuca and San Juan Archipelago are comparable, because of their composition, to the shales (Table 2) but have a higher nickel content. This high nickel content may be attributed to organic matter and to the adsorption of nickel ions by clay particles. The source of nickel, aside from that occurring in the inflowing waters, may be the result of freshwater runoff and the weathering and halmirolysis of rocks. This influx of nickel is removed from the surface layers by organisms or by adsorption by clay particles. A portion of these nickel scavengers eventually become sedimentized.

A series of sediment samples was collected on a course from near the entrance of the Strait of Juan de Fuca, across the continental shelf to the deep water of the Pacific. These results, given in Table 10, demonstrate that the nickel content of the sediments appreciably increases seaward. It may be assumed that nickel is halmirolysed from shallow-water sediments ( $Y$ ou $\mathrm{ng}, 1954$ ) and enriched in deep-sea deposits by scavenging manganic hydroxide (Gold be r g, 1954). As indicated above, organic matter, clay minerals, and iron hydroxide may be as effective scavengers as manganese hydroxide. Further evidence of the effectiveness of iron as a scavenger is indicated by the high nickel content of marine oolitic iron ores. From the data given in Table 9 it 
Table 10.

Nickel content of marive sediments.

\begin{tabular}{|c|c|c|c|}
\hline Place of collection & $\begin{array}{l}\text { Depth } \\
\text { m. }\end{array}$ & Description of sediment & Ji mg.-at. $/ \mathrm{Kg}$. \\
\hline $\begin{array}{l}\text { Florida } \\
\text { Tampa Bay } \\
\text { Charlotte Harbor }\end{array}$ & $\begin{array}{l}3 \\
3 \cdot 5\end{array}$ & $\begin{array}{l}\text { Quartz sand } \\
\text { Sandy mud }\end{array}$ & $\begin{array}{r}0.024 \\
.082\end{array}$ \\
\hline $\begin{array}{l}\text { Puget Sound Area } \\
\text { Carr Inlet, Still Harbor } \\
\text { Hood Canal } \\
\text { Jefferson Head }\end{array}$ & $\begin{array}{l}112 \\
148 \\
278\end{array}$ & $\begin{array}{l}\text { Silty clay and mud } \\
\text { Silty clay and mud } \\
\text { Silty clay and mud }\end{array}$ & $\begin{array}{l}.62 \\
.66 \\
.75\end{array}$ \\
\hline $\begin{array}{l}\text { San Juan Archipelago } \\
\text { East Sound, Orcas Island } \\
\text { San Juan Canal }\end{array}$ & $\begin{array}{l}25 \\
75\end{array}$ & $\begin{array}{l}\text { Silty organic mud } \\
\text { Silty clay and mud }\end{array}$ & $\begin{array}{l}.57 \\
.62\end{array}$ \\
\hline $\begin{array}{l}\text { Strait of Juan de Fuca } \\
48^{\circ} 13 \text { N., } 122^{\circ} 53^{\prime} \mathrm{W} . \\
48^{\circ} 14^{\prime} \mathrm{N} ., 123^{\circ} 24^{\prime} \mathrm{W} . \\
48^{\circ} 17^{\prime} \mathrm{N} ., 124^{\circ} 02^{\prime} \mathrm{W} .\end{array}$ & $\begin{array}{r}46 \\
127 \\
188\end{array}$ & $\begin{array}{l}\text { Gravel and organic matter } \\
\text { Sandy mud } \\
\text { Sand }\end{array}$ & $\begin{array}{l}.95 \\
.51 \\
.36\end{array}$ \\
\hline $\begin{array}{l}\text { North-east Pacific Ocean, } \\
\text { Continental Shelf } \\
47^{\circ} 45^{\prime} \mathrm{N} ., 125^{\circ} 02^{\prime} \mathrm{W} . \\
47^{\circ} 46^{\prime} \mathrm{N} ., 125^{\circ} 05^{\prime} \mathrm{W} . \\
48^{\circ} 06^{\prime} \mathrm{N} ., 125^{\circ} 10^{\prime} \mathrm{W} . \\
47^{\circ} 55^{\prime} \mathrm{N} ., 125^{\circ} 30^{\prime} \mathrm{W} . \\
47^{\circ} 50^{\prime} \mathrm{N} ., 125^{\circ} 35^{\prime} \mathrm{W} . \\
47^{\circ} 50^{\prime} \mathrm{N} ., 125^{\circ} 43^{\prime} \mathrm{W} . \\
47^{\circ} 50^{\prime} \mathrm{N} ., 125^{\circ} 48^{\prime} \mathrm{W} . \\
47^{\circ} 54^{\prime} \mathrm{N} ., 126^{\circ} 06^{\prime} \mathrm{W} .\end{array}$ & $\begin{array}{r}141 \\
208 \\
456 \\
640 \\
841 \\
1180 \\
1490 \\
1848\end{array}$ & $\begin{array}{l}\text { Sand and silt } \\
\text { Sandy silt } \\
\text { Silt and clay } \\
\text { Clay } \\
\text { Clay } \\
\text { Clay } \\
\text { Clay } \\
\text { Clay }\end{array}$ & $\begin{array}{r}.54 \\
.53 \\
.63 \\
.87 \\
.94 \\
.81 \\
1.05 \\
1 \cdot 10\end{array}$ \\
\hline $\begin{array}{l}\text { Gulf of Alaska } \\
53^{\circ} 15^{\prime} \text { N., } 149^{\circ} 20^{\prime} \text { W. }\end{array}$ & 4390 & $\begin{array}{l}\text { Diatom ooze } 2-4 \mathrm{~cm} \text {. } \\
\text { below sediment surface }\end{array}$ & 1.8 \\
\hline $54^{\circ} 08^{\prime}$ N., $141^{\circ} 15^{\prime} \mathrm{W}$. & 3620 & $\begin{array}{l}\text { Diatom ooze with red clay } \\
2-4 \mathrm{~cm} \text {. from sediment } \\
\text { surface }\end{array}$ & 2.90 \\
\hline $54^{\circ} 08^{\prime}$ N., $141^{\circ} 15^{\prime} \mathrm{W}$. & 3620 & $\begin{array}{l}\text { Foram ooze } 110-112 \mathrm{~cm} \text {. } \\
\text { from sediment surface }\end{array}$ & .66 \\
\hline $56^{\circ} 14$ N., $152^{\circ} 58^{\prime} \mathrm{W}$ & 970 & $\begin{array}{l}\text { Terrigenous clay } 55-57 \mathrm{~cm} \text {. } \\
\text { below sediment surface }\end{array}$ & .68 \\
\hline $\begin{array}{c}\text { Bering and Chuckchee Seas } \\
74^{\circ} 14^{\prime} \mathrm{N} ., 162^{\circ} 47^{\prime} \mathrm{W} . \\
70^{\circ} 55^{\prime} \mathrm{N} ., 158^{\circ} 67^{\prime} \mathrm{W} . \\
68^{\circ} 19^{\prime} \mathrm{N} ., 166^{\circ} 41^{\prime} \mathrm{W} . \\
66^{\circ} 12^{\prime} \mathrm{N} ., 162^{\circ} 40^{\circ} \mathrm{W} .\end{array}$ & $\begin{array}{l}30 \\
25 \\
20 \\
14\end{array}$ & & $\begin{array}{l}.13 \\
.17 \\
.45 \\
.51\end{array}$ \\
\hline
\end{tabular}

appears that the formation of calcareous material also may be considered as a scavenger of nickel. Such being the case, the nickel in the calcareous debris will be subjected to halmirolysis.

In such a complex system as exists on or near the sea floor, halmirolysed nickel will tend to be reprecipitated or re-adsorbed by substances giving a more stable and less soluble form. Thus calcium 
carbonate is subjected to a slow re-arrangement because of the chemical nature of the carbonate-bicarbonate-carbonic acid system. Some of the nickel liberated will be scavenged by the iron or manganese compounds, becoming very insoluble because of the characteristics of the iron or manganese compounds and the basic nature of the system.

\section{Acknowledgement.}

The authors wish to express their appreciation for financial assistance from the Office of Naval Research ${ }^{1}$ ), to Mr. Lew D odd, of Yellow Island in the San Juan Islands, for collecting water samples, and to their colleagues in the Department of Occanography for many suggestions and criticisms.

\section{Summary.}

Methods for the analysis of nickel in sea water, in particulate material, and in marine organisms were investigated and modified. By using collectors already present in sea water and sodium carbonate solution as the precipitant, a more satisfactory recovery of nickel was obtained. In the preliminary treatment of marine organisms for nickel analysis, wet combustion was preferred to direct ashing as a relatively large proportion of nickel appears to be carried off with the smoke. As nickel may be removed from solution by biological activity, samples of water should be treated immediately after sampling. Sea water from Puget Sound and adjacent areas contain about $0.034 \mu \mathrm{g}$.-at. of nickel per kilogramme in solution and $0.005 \mu$ g.-at. of nickel as particulate. River and lake waters contain slightly less soluble nickel than is found in sea water. The plankton examined contained twice as much nickel as the higher marine plants and more than ten times the amount found in the fish and molluscs examined. Indications are that plankton collected in the euphotic layers contained about twice the concentration found near the aphotic zone, and that nickel is probably concentrated by bacteria. Plants and animals concentrate nickel in their calcareous skeletons in the same degree as in soft organic tissues.

The amount of nickel in the sediments collected across the continental shelf to the deep sea increased as the depth of water and distance from shore increased.

Nickel is halmirolysed from shallow-water sediments and enriched in deep-sea deposits by several scavengers.

1) Contract No. N80NR-520/III, Project NR083-012.

\section{References.}

Bertrand, G., \& M. Mâcheboeuf, 1925. "Presence of nickel and cobalt in animal tissues". Compt. Rend., 180: 1380-3.

Bertrand, G., \& M. Mokragnatz, 1930. "Distribution of nickel and cobalt among plants". Compt. Rend., 190: 21-5.

B l a ck, W. A. P., \& R. L. M itch ell, 1952. "Trace elements in the common brown algae and in sea water". J. Mar. Biol. Ass. U. K., 30, 3: 575-84.

B ow e n, V. T., \& D. S u t t o n, 1951. "Comparative studies of mineral constituents of marine sponges". J. Mar. Res., 10, 2: 153-67. 
Cla rke, F. W., 1924. "The data of geochemistry". U. S. Geol. Survey Bull., 770, $841 \mathrm{pp}$.

Ericson, L. E., \& L. Lewis, 1953. "On the occurrence of vitamin $B_{12}$ factors in marine algae". K. Sv. Vetensk.-Akad., Ark. f. Kemi, 6, 5: 427-42.

E rnst, T., \& H. Hörmann, 1936. "Bestimmung von Vanadium, Nickel und Molybdän im Meerwasser". Gesellsch. d. Wiss. Göttingen, Math.-Phys. KI., Fachgr. IV, Geol. u. Mineral., 1: 205-8.

Fl e m in g, R. H., 1940. "Composition of plankton and units for reporting populations and production". VI. Pac. Sci. Congr., Calif., 1939, Proc., 3: 535-40.

F ox, H. M., \& H. A. R a m a g e, 1931. "Spectrographic analysis of animal tissues". Proc. Roy. Soc., B., 108: 157-73.

Goldberg, E. D., 1954. "Marine geochemistry. 1. Chemical scavengers of the sea". Journ. Gcol., 62, 3: 249-65.

Goldsmidt, V. M., 1937. "Geochemische Verteilungsgesetz der Elemente. IX. Die Mengenverhältnisse der Elemente und der Atom-A rten". Skr. Norske Vidensk.Akad., Oslo, I Mat.-Naturv. Kl., 4: 148 pp.

Golds m id t, V. M., 1954. "Gcochemistry". Clarendon Press, Oxford.

Institute of Seaweed Research, 1953. Annual Report 1953, Inveresk, Midlothian. $48 \mathrm{pp}$.

I s h i ba s h i, M., 1953. "Studies on minute elements in sea water". Rec. Occanogr. Works in Japan, 1, 1: 88-93.

Ishibashi, M., T. Shigematsu, \& Y. Nakagawa, 1951. "Quantitative determination of nickel and cobalt in sea water". Bull. Inst. Chem. Res., Kyoto Univ., 26: 68.

Le w i s, G. E., \& E. D. Gold b c rg, 1954. "Iron in marine waters". J. Mar. Res., 13, 2: 183-97.

L und e gå rd h, P. H., 1949. "Aspects to the geochemistry of chromium, cobalt, nickel and zinc". Sveriges Geol. Unders. Ser. C, Avh. och Upps., No. 513, Årsbok 43, No. 11: 56 pp.

Ma l juga, D. P., 1939. "Geochemistry of scattered nickel. I. Distribution of nickel in organisms and in the biosphere". Trav. Lab. Biogéochim. Acad. Sci,, U.R.S. S., 5: $91-111$.

- 1945. "Content of copper, nickel, cobalt and other elements of iron family in native waters". Dok. Akad. Nauk S. S. S. R., 48, 2: 113-6.

Monier-Williams, G. W., 1949. "Trace elements in food". J. Wiley \& Sons, N. Y., 511 pp.

Noddack, I. \& W., 1939. "Dic Häufigkeit der Schwermetalle in Mecrestieren". Ark. f. Zool. B 32 A No. 4: 1-35.

R a n k a ma, K., \& Th. G. S a h a ma, 1949. "Geochemistry". Univ. Chicago Press. $912 \mathrm{pp}$.

S a ndeli, E. B., 1950. "Colorimetric determination of traces of metals". Interscience Publ. Inc. N. Y., 673 pp.

S a nde 11, E. B., \& S. S. Goldich, 1943. "The rarer metallic constituents of some American igneous rocks". I. J. Geol. 51: 99-115, II, ibid: 167-89.

S c ot t, R. O., \& R. L. M it c h ell, 1943. "Concentration methods in spectrographic analysis. I. Recovery of cobalt, nickel, molybdenum, copper and zinc from plant materials and soil extracts by 8-hydroxyquinoline". J. Soc. Chem. Ind., 62: 4-8.

$S t$ il e s, W., 1948. "Trace elements in plants and animals". Cambridge Univ. Press, N. Y.

Thomp so n, T. G., \& T. J. Ch ow, 1955. "A non-metallic water sampler". Deep Sea Research, 2, 3: 200-3.

Vin o gra dov, A. P., 1944. "Geochemistry of scattered rare elements in sea water". Uspekhi Khimii, 13: 3-34. (In Russian).

- 1935. "Elementary chemical composition of marine organisms. Pt. I". Trav. Lab. Biochim., Acad. Sci., U.R. S. S., 3: 63-278. (In Russian).

- 1937. “...... Pt. 2". Ibid., 4: 5-225. (In Russian).

Vin og rado v, A. P., \& V. W. Od um, 1953. "The elementary chemical composition of marine organisms". Memoir II, Sears Found. Mar. Res., New Haven, $647 \mathrm{pp}$. 
Vog t, J. H. L., 1923. "Nickel in igneous rocks". Econ. Gcol., 18: 307.

Wallace, T., 1952. "The application of the method of visual diagnosis to trace elements problems in plants. Trace elements in plant plysiology". Chron. Bot. Co., Waltham, Mass.: 5-9.

Wells, R. C. "Analyses of petroleum-coke ashes". U. S. Geol. Survey Bull., 950: $3-5$.

Young, E. J., 1954. "Trace elements in recent marine sediments". Program 1954, Annual Meetings, Geol. Soc. America, et al., Nov. 1954: 125. 


\section{Department of Oceanography \\ University of Washington}

UNCLASSIFIED RECHNICAI REPORT DISTRIBUTION IIST

3 Chilef of Naval Research

Department of Navy

Washington 25, D.C.

Attn: Code 446 (I)

463 (1)

466 (1)

1 Commanding Officer

Offloe of Naval Research Branch Office 346 Broadway

$\therefore$ New York 13, New York

1 Commanding officer Office of Naval Research Branch Office John Crerar Itbrary Building

86 Fast Randolph Street

Chicago 1, IIIinols

1 Conmanding Officer Office of Naval Research Branch Office 1030 East Green Street

Pasadena 1, California

1 Commanding Officer

Office of Naval Research Branch Office 1000 Geary Street

San Francisco 9, California

3 Commanding officer

Office of Naval Research Branch Office Navy \#100, Fleet Post Office

New York, New York

2 Office of Naval Research

Geophysics Branch

Washington 25, D.C.

Attn: 416

1 Office of Naval Research Resident Representative

University of Washington

Seattle 5, Washington

2 Chief, Bureau of Aeronautics

Department of the Navy

Washington 25, D.C.

Attis PH 41 (I)

AY $-3(1)$
3 Chief, Bureau of Ships

Department of the Navy

Washington 25, D.C.

Attn: Code 312 (I)

320 (1)

845 (1)

1 Chief, Bureau of Iards and Docks

Department of the Navy

Washington 25, D.C.

1 Chief of Naval Operations

Depertment of the Navy

Washington 25, D.C.

Attn: 0p-533D

1 Commander, Naval Ordnance

Iaboratory, White Oak

Silver Spring 19, Maryland

1 Commanding officer

U. S. Navy Mine Countermeasure Station

Panama City, Florida

1 Commanding Officer

U. S. Navy Underwater Sound Laboratory

New London, Connecticut

2 Department of Aerology

U.B. Naval Post Graduate School

Monterey, California

3 Director, U.S. Navy Electronics Iaborad

San Diego 52, California

Attn: 2230

6 Director, Naval Research Laboratory

Washington 25, D.C.

Attn: Technical Services

Information officer

8 Hydrographer

U.S. Navy Hydrographic Offlce

Washington 25, D.C.

Attn: Division of Oceanography

10/20/54 (Rev. 6/21/56) 
1 Project Arowa

U. S. Naval Air Station

Building $\mathrm{R}=48$

Norfolk,Virginia

1 Superintendent, U.S. Naval Acedeng innapolis, Maryland

5 Armed Services Technical Information Center

Documents Service Center

Knott Building

Dayton 2, Ohio

1 Assistant Secretary of Defense for Research and Development

Pentagon Building

Washington 25, D.C.

Attn: Committed on General Sciences 1

1 Chief, Air Weather Service Department of the Air Force Washington 25, D.C.

1 Chter, Armed Forces

Special Weapons Project

P.0. Box 2610

Washington D.C.

2 Chief, U.S. Weather Bureau

2400 i Street N.W.

Washington 25, D.C.

Attn: Dr. H. Wexler

1 Commandant (OAO)

U. S. Coast Guard

Department of the Treasury

Washington 25, D.C.

I Commanding General

Research and Development Division

Department of the Air Force

Washington 25, D.C.

1 Commanding General

Research and Development Division

Department of the Army

Washington 25, D.C.
1 Commanding officer

Cambridge Field Station

230 Albany Street

Cambridge 30, Massachusetts

Attn: CRHSL

1 DIrector, U.S. Coast \& Geodetio Survey Department of Commerce

Washington 25, D.C.

2 Director, U.S Fish \& WIIdlife Service

Department of the Interior

Washington 25, D.C.

Attn: Dr. I. A. Walford

I National Research Council

2101 Constitution Avenue

Washington 25, D.C

Attn: Committee on Undersea Warfare

1 Office of Technical Services

Department of Commerce

Washington 25, D.C.

1 U.S. Army Beach Erosion Board 5201 Little Falls Roed N.W. Weshington 16, D.C.

2 U.S. Fish \& Wilduife Service Pacific Oceanic Fishery Investigation

a P.0. Box 3830

Honolulu, T.H.

Attn: Librarian (I)

$$
\text { T. S. Aubtin(1) }
$$

I U.S. Fish \& Wildiffe Service

Soripps Institution of Deanography Ia Jolla, Caltfornia

1 U.S. Fish \& Wildilfe Service Woods Hole

Massachusetts

1 O.S. Waterways Experiment Station Vicksburg, Mississippi

1 Allen Hancock Foundation University of Southern California Ios Angeles 7, Calffornia 
1 Bingham Oceanographic Laboratories

Yale University

New Haven, Connecticut

I Department of Conservation

Cornell University

Ithaca, New York

Attn: Dr. J. C. Ayers

1 Department of Engineering

University of California

Berkeley, California

1 Department of Meteorology \& Oceanography

College of Engineering

New York University

University Heights, New York 53, N.I.

Attn: Dr. W. J. Pierson

1 Department of Zoology

Rutgers University

New Brunswick, New Jersey

Attri; Dr. H. K. Hasking

I Director, Bermuda Biological Station for Research

St. George's, Bermuda

1 Birector, Chesapeake Bay Institute

Box 42 R.F.D. \#2

Aginapolis, Maryland

1 Director, Hawaii Marine Laboratory University of Hawaii

Honolulu, T.H.

1 Director, Lamont Geological Observatory Torrey Cliff

Palisades, New York

1 Director, Marine Laboratory

University of Niami

Coral Cables, Florida

1 Director, Narragansett Marine Laboratory Kingston, Rhode Island
1 Director, National Institute of Oceanography Wormley, Near Godalming Surry, England

2 Director, Scripps Institution of

- Ocaanography

La Jolla, California

2 Director, Woods Hole Oceanographic Institution

Woods Hole, Massachusetts

1 Dr. Wayne V. Burt

Oregon State College

Corvallis, Oregon

1 Head, Department of Oceanography

Texas A \& M College

College Station, Texas

1 Hudson Laboratories

Columbia University

145 Palisades Street

Dobbs Ferry, New York

1 Institute of Odeanography

Univeristy of British Columbia

Vancouver, British Columbia, Canada

2 Project officer

Laboratory of Oceanography

Woods Hole, Massachusetts 